\title{
Transaction Cost in Irrigation Tank Management: An Institutional Economic Analysis
}

\author{
Ravi, S.C.", K.B. Umesh and P.S. Srikantha Murthy \\ Department of Agricultural Economics, University of Agricultural Sciences, Bangalore, India \\ *Corresponding author: ravisc3@gmail.com
}

\begin{abstract}
Irrigation tanks formed the lifeline of village economy. The Government of Karnataka amended its Irrigation Act in 1965 and Participatory Irrigation Management (PIM) was brought under the domain of Cooperative Act and Water Users Cooperatives were formed to managed and operate the tanks. The present study was undertaken to assess the transaction cost in irrigation tank management in central dry zone of Karnataka. Two tanks Bukkarayanakere (farmers managed) and Ayyanakere (Minor Irrigation Department managed) were considered for the study. The results revealed that, total transaction cost incurred was high in Minor Irrigation Department managed tank or defunct water users association (₹ 1,06,085 per year) than farmers managed tank or active water users association ( $₹$ 61,480 per year). This is because of free riding problem that prevailed in the Minor Irrigation Department managed tank command. Educating the farmers regarding the benefits of collective action is necessary to reduce the transaction cost.
\end{abstract}

Keywords: Transaction cost, irrigation tanks, collective action, free riding, water users association

Irrigation tanks formed the lifeline of the rural communities in providing irrigation to crops and local ecosystem in South India (Gandhiraj, 2007). Irrigation systems in India are mostly open access resources/common property resources. Common property resources are often subjected to the problem of free riding and lack of collective action. Collective action problems arise when farmers have an incentive to use more water and invest less in the system. Allocation of water and provisions are two major sources of collective-action problems. Problems of collective action are more predominant in irrigation systems when compared to other types of common property resources (Ostrom et al. 1994).

Realizing the needs, States took efforts to foster participation of farmers in the management of irrigation systems in India. Karnataka State amended its Irrigation Act in 1965 (Anon, 2000) and Participatory Irrigation Management (PIM) was brought under the domain of Cooperative Act. "Irrigation management transfer" was one of the reforms under this policy which emphasizes paradigm shifts in irrigation management from state management to Water Users Association (WUAs). Each WUA has distinct institutions (rules and regulations) in managing, operating and distribution of water.

Transaction costs are incurred during the formation of WUAs i.e. the expenses incurred in mobilizing the participators and developing institutional framework. Transaction costs are also incurred annually for the functioning of WUAs. Institutions (WUAs) are often referred to as transaction cost reducing mechanisms. Despite this, there exists some transaction cost in collective action. Nevertheless, transaction cost varies from institution to institution based on the collective action. Operation and governance of the WUAs has a direct impact on the transaction costs.

Analysis of transaction costs helps in designing the recommendations for water related institutions. With this backdrop, study focuses on estimation of transaction cost involved in governing the tank 
institutions in Bukkarayanakere and Ayyanakere (managed by farmers and Minor Irrigation Department, respectively) in Central Dry Zone of Karnataka. In this study it was hypothesized that, transaction costs of governance are less in the tank managed by farmers than by MID.

\section{METHODOLOGY}

\section{Study area and sampling}

The study was carried out in the Central Dry Zone of Karnataka during the agriculture year 201718. Two tanks in Central Dry Zone of Karnataka were selected purposively, one under farmers management (Bukkarayana Kere) and the other tank managed by the MID (Ayyana Kere). Farmers were selected based on random sampling technique. Data was collected from 90 farmers using pre-tested wellstructured schedule through personal interview method. After omitting outliers, data of 80 farmers from each management regime was considered for the analysis.

\section{Transaction cost}

Transaction cost includes information cost, contractual cost and enforcement cost as enunciated by Coase (1960). The analysis considers the cost of gathering information regarding the formation of WUA, cost of preparing documents and submitting them to the concerned office, rent seeking (if any) in order to receive the benefit from any Governmental programme. Besides, establishing one's bargaining position and arriving at a group decision, cost incurred to collect water fee, cost incurred to enforce the decision made were also considered. Time spent by farmer in attending the group meeting, annual meetings, guarding activity has been calculated by considering the opportunity cost of the labour under prevailing wage rate (Kolla and Chandrakanth, 2013).

\section{RESULTS}

\section{Operation and maintenance cost of tanks}

The total operation and maintenance cost incurred in farmers managed and MID managed tanks are presented in Table 1. The operation and maintenance cost included the expenditure on reconstruction of bunds, repair of sluice gate and spillways, cement lining of irrigation channels and de-silting of tanks. Since the operation and maintenance expenditure is not incurred in a single year, the expenditure from 2000 till 2018 was considered.

In both the tanks, the expenditure was higher on lining of irrigation channels ( $₹ 30$ lakh and ₹ 640 lakh in farmers managed and MID managed tanks, respectively) which was followed by reconstruction of bunds ( $₹ 25$ lakh and ₹ 180 lakh in farmers managed and MID managed tanks, respectively). Total operation and maintenance cost per ha of command area was ₹ 0.97 lakh and ₹ 0.60 lakh in farmers managed and MID managed tank areas, respectively. In addition to this the salary for neerkatti was $₹ 40,000$ per year in farmers managed tank, whereas it was ₹ 1,50,000 per year in MID managed tank. Neerkatti is a person appointed and paid by the water users association during the time of water release from tank to ensure equity in distribution of tank water among all the users. Neerkatti will inform the farmers one or two days in advance regarding the time and date of release of water to the field. It is the duty of Neerkatti to inform the members of water users association if any farmer is drawing the water illegally.

The Total operation and maintenance cost per ha of command area per year (including salary of neerkatti) was lower in farmers managed $(₹ 7,611)$ than MID managed tank (₹ 11,667). The operation and maintenance cost incurred was directly related to the performance of tanks. On the contrary, Palanisami (2006) reported that the operation and maintenance cost incurred and the level of tank performance were not directly related.

\section{Transaction costs of governance of tank management institutions}

\section{Farmers managed tank area}

The Transaction Cost (TC) of governance of tank management institutions in farmers managed and MID managed tanks comprised of information cost, contractual cost and enforcement cost. These costs in turn are subdivided into One Time Expenditure (OTE) and Annual Expenditure (AE). One time expenditure is the expenditure made during the establishment of water users association. Annual expenditure is incurred every year to sustain its operation. 
Table 1: Operation and maintenance cost of tanks from 2000-2018

\begin{tabular}{cccc}
\hline S1. No. & Particulars & $\begin{array}{c}\text { Farmers Managed Tank area } \\
\text { (₹ in lakh) }\end{array}$ & $\begin{array}{c}\text { MID Managed Tank } \\
\text { area (₹ in lakh) }\end{array}$ \\
\hline 1 & Reconstruction of Bunds & 25 & 180 \\
2 & Repair of Sluice gate/spillways & 1.50 & 43 \\
3 & Lining of irrigation channels & 30 & 640 \\
4 & De-silting of tanks & 17.50 & 85.5 \\
& Total operation and maintenance cost & 74 & $\mathbf{9 4 8 . 5 0}$ \\
Total operation and maintenance cost per ha of command area & 0.97 & $\mathbf{0 . 6 0}$ \\
5 & Salary for Neerkatti (₹ in lakh per year) & 0.40 & 1.5 \\
\multicolumn{2}{c}{ Total operation and maintenance cost per ha of command area } \\
\multicolumn{2}{c}{ per year (including salary of Neerkatti) }
\end{tabular}

Source: Minor Irrigation and Groundwater Development Board, Chikkamagaluru.

Note: MID- Minor Irrigation Department.

Table 2: Transaction cost involved in establishment and sustenance of tank WUA managed by the farmers' (Active WUA)

\begin{tabular}{|c|c|c|c|c|}
\hline \multicolumn{3}{|c|}{ (a) Information cost } & \multirow[t]{2}{*}{$₹$} & \multirow[t]{2}{*}{ Per cent } \\
\hline \multirow{7}{*}{ OTE } & 1 & Cost incurred by the President & & \\
\hline & & a. To attend the meeting in Chikkamagaluru (3) & 75 & 0.12 \\
\hline & & b. Opportunity cost of time (2 hours per meeting) & 750 & 1.22 \\
\hline & 2 & Cost incurred to inform all the farmers about formal registration of WUA & 250 & 0.41 \\
\hline & 3 & Opportunity cost of service of Government agency & 1,500 & 2.44 \\
\hline & 4 & Expenditure on telephonic calls to inform farmers regarding the meeting & 130 & 0.21 \\
\hline & Tota & OTE of information cost & 2,705 & 4.40 \\
\hline \multicolumn{5}{|c|}{ (b) Contractual Cost } \\
\hline \multirow{5}{*}{ OTE } & 1 & Opportunity cost of farmers (70 No.) in attending the meetings ( 2 meetings, 0.5 hour) & 1,094 & 1.78 \\
\hline & 2 & $\begin{array}{l}\text { Opportunity cost of President and members in conducting meeting ( } 2 \text { meetings, } 1 \\
\text { hour) }\end{array}$ & 313 & 0.51 \\
\hline & 3 & Snacks and tea served in the meetings & 1,100 & 1.79 \\
\hline & 4 & Documents and Registration of the Society & 2,500 & 4.07 \\
\hline & 5 & Cost incurred to open a bank account & 900 & 1.46 \\
\hline \multirow{4}{*}{$\mathrm{AE}$} & Tota & OTE of contractual cost & 5,906 & 9.61 \\
\hline & 6 & Expenditure in general meetings (Breakfast/Snacks) & 5,500 & 8.95 \\
\hline & 7 & $\begin{array}{l}\text { Opportunity cost of time spent by the farmers ( } 45 \text { No.) in attending the meeting ( } 3 \\
\text { meetings, } 0.45 \text { hour) }\end{array}$ & 5,906 & 9.61 \\
\hline & Tota & AE of contractual cost & 11,406 & 18.55 \\
\hline \multicolumn{5}{|c|}{ (c) Enforcement Cost } \\
\hline OTE & 1 & Opportunity cost of labour for collecting the records of members & 150 & 0.24 \\
\hline \multirow[t]{2}{*}{$\mathrm{AE}$} & 2 & Opportunity cost of president and members in attending meeting at Sakarayapattana & 1,313 & 2.13 \\
\hline & 3 & Salary to neerkatti ( $₹ 400 * 100$ days) & 40,000 & 65.06 \\
\hline \multicolumn{3}{|c|}{ Total AE of Enforcement cost } & 41,313 & 67.20 \\
\hline \multicolumn{3}{|c|}{ Total transaction cost } & 61,480 & 100.00 \\
\hline
\end{tabular}

Note: OTE: One Time Expenditure and AE: Annual Expenditure.

Since there was equity in the distribution of water the transaction cost remains same for head as well as tail reach farmers. The estimated transaction cost in farmers managed tank was ₹ 61,480 per year (Table 2). Of which, major cost was incurred on enforcement cost $(67.44 \%)$ followed by contractual cost $(28.16 \%)$ and information cost $(4.40 \%)$. The results are in consonance with study conducted by Sripadmini (2000) where she reported that the enforcement cost (71\%) which was higher than information cost and contractual cost in Government watershed. Total OTE was ₹ 5,906 which mainly comprised of cost incurred on documents and registration of society (₹ 2,500), snacks and tea served during the meeting 
(₹ 1,100) and opportunity cost of farmers in attending the meetings ( $₹ 1,094)$.

Annual expenditure on enforcement cost consisted of opportunity cost of president and members in attending the meeting at Minor Irrigation Department office located at Sakarayapattana $(2.13 \%$ of TC) to arrange the supply of water to the tank from Madaga tank (BBukkarayanakere tank receives water from largest tank in Kadur taluk called Madaga tank) and salary to Neerkatti (65.06\% of TC).

\section{MID managed tank area}

Since there was no equity in the distribution of tank water between head and tail reach farms, the transaction cost of governance is different for head and tail reach farmers and the results of the same are presented in Table 3.
The total transaction cost was ₹ 20,566 and ₹ $1,91,604$ per year for the farmers in head and tail reach, respectively. OTE on information cost and contractual cost remains same for both head and tail reach farmers since they both were the members of water users association during establishment. The information cost accounted for 16.09 per cent and 1.73 per cent of the transaction cost for head and tail reach farmers, respectively and was lower than contractual and enforcement costs. The results of the study are contradictory to the findings of study by Durga et al. (2015) where search and information cost was higher than contractual cost. The one time expenditure on contractual cost was ₹ 3,781 per year $(18.39 \%$ and $1.97 \%$ of TC in head and tail reach areas, respectively). Annual expenditure of contractual cost was zero for head reach farmers because the water users association was defunct and no meetings were held. But the farmers in tail

Table 3: Transaction cost involved in establishment and sustenance of tank WUA managed by the MID (Passive WUA)

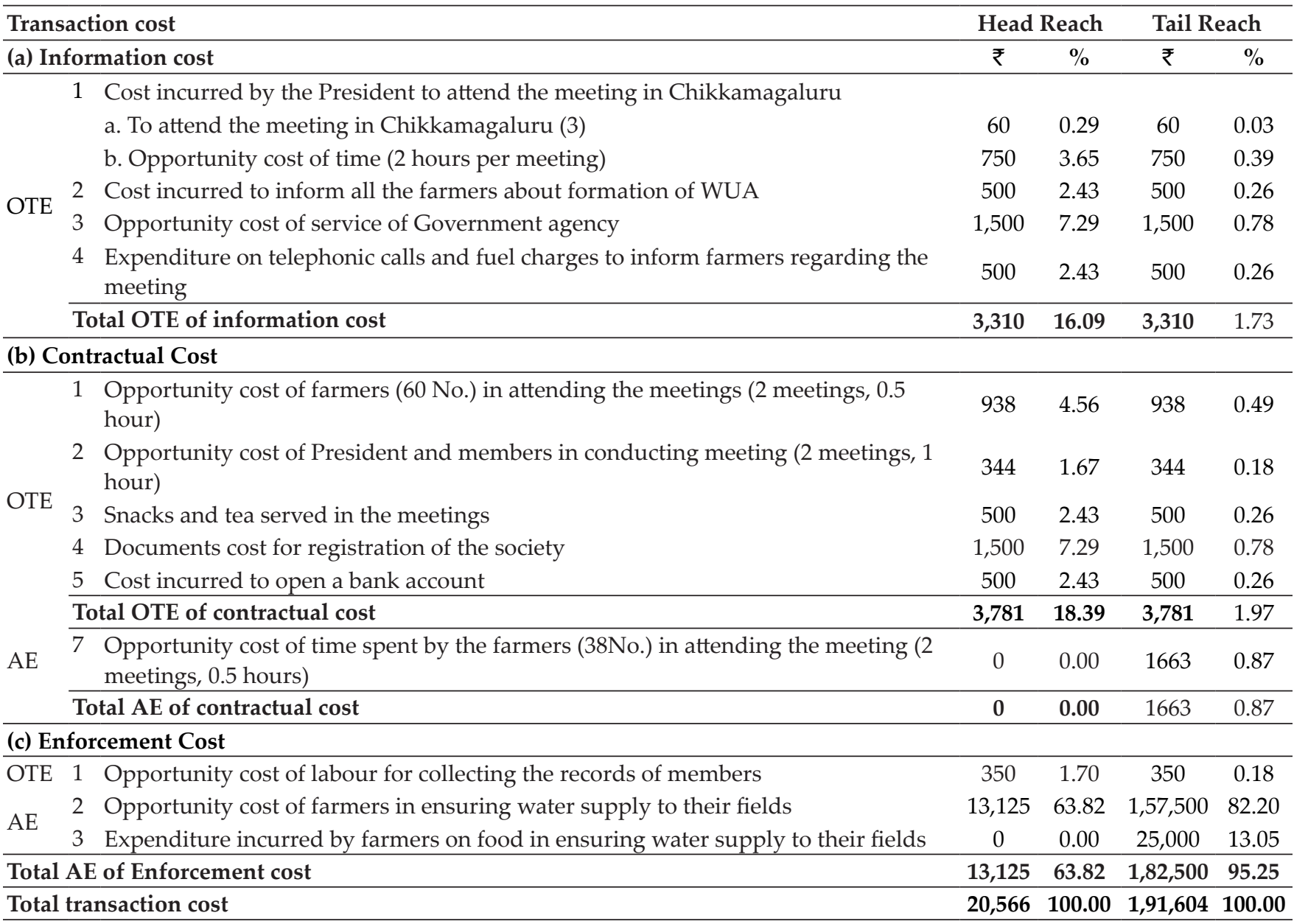

Note: OTE: One Time Expenditure and AE: Annual Expenditure. 
Table 4: Transaction cost involved in establishment and sustenance of tank water users association per ha and per member

\begin{tabular}{|c|c|c|c|c|c|c|c|c|c|c|}
\hline \multirow[b]{2}{*}{ S1. No } & \multirow[b]{2}{*}{ Particulars } & \multicolumn{2}{|c|}{ Information cost } & \multicolumn{2}{|c|}{ Contractual cost } & \multicolumn{2}{|c|}{ Enforcement cost } & \multirow{2}{*}{$\begin{array}{l}\text { Total } \\
\text { cost (₹) }\end{array}$} & \multirow{2}{*}{$\begin{array}{l}\text { Transaction } \\
\text { cost per ha } \\
\text { (₹) }\end{array}$} & \multirow{2}{*}{$\begin{array}{l}\text { Transaction } \\
\text { cost per } \\
\text { member (₹) }\end{array}$} \\
\hline & & $\begin{array}{c}\text { Total } \\
\text { cost (₹) }\end{array}$ & $\begin{array}{c}\text { Cost per } \\
\text { ha (₹) }\end{array}$ & $\begin{array}{c}\text { Total } \\
\text { cost (₹) }\end{array}$ & $\begin{array}{c}\text { Cost per } \\
\text { ha (₹) }\end{array}$ & $\begin{array}{c}\text { Total } \\
\text { cost (₹) }\end{array}$ & $\begin{array}{c}\text { Cost per } \\
\text { ha (₹) }\end{array}$ & & & \\
\hline \multicolumn{11}{|c|}{ Farmers Managed Tank } \\
\hline 1 & OTE & 2,705 & 22 & 5,906 & 47 & 150 & 1 & 8,761 & 70 & 110 \\
\hline 2 & $\mathrm{AE}$ & 0 & 0 & 11,406 & 91 & 41,313 & 330 & 52,719 & 421 & 659 \\
\hline 3 & Total TC & 2,705 & 22 & 17,313 & 125 & 41,463 & 331 & 61,480 & 491 & 769 \\
\hline \multicolumn{11}{|c|}{ MID Managed Tank } \\
\hline 4 & OTE & 3,310 & 79 & 3,781 & 90 & 350 & 8 & 7,441 & 177 & 186 \\
\hline 5 & $\mathrm{AE}$ & 0 & 0 & 831 & 23 & 97,813 & 2,583 & 98,644 & 2,605 & 2,466 \\
\hline 6 & Total TC & 3,310 & 79 & 4,613 & 112 & 98,163 & 2,591 & $1,06,085$ & 2,782 & 2,652 \\
\hline
\end{tabular}

Note: OTE: One Time Expenditure; AE: Annual Expenditure and MID: Minor Irrigation Department.

reach incurred a cost of ₹ 1,663 per year because of opportunity cost of labour. The farmers of tail end area met together and discussed on the next steps to be taken to ensure the water supply to their fields.

The annual expenditure on enforcement cost accounted for 64 per cent and 95 per cent of the total transaction cost for head and tail reach farmers, respectively. The farmers in the head reach had to ensure that no one draws water illegally when it was their turn to use the water. Hence, the opportunity cost of labour in ensuring amounted to ₹ 13,125 per year.

The farmers in the tail end reach had to guard whole day and night to make sure that the farmers in head reach will not use water illegally. Nearly 5 farmers each at three main points had to guard the channels for nearly 10 days. Each farmer on an average spent about six hours a day in guarding. Hence, the opportunity cost of labour in guarding the channel amounted to $₹ 1,57,500$ per year. The total transaction time spent by the farmers in tail reach was higher than the farmers in head reach andwa because of free riding and illegal use of irrigation water by the head reach farmers. Bhattari (2010) reported that, total transaction time was more for the farmers at downstream (32 man days) as against 20 man days for the farmers in upstream of the canal.

It is clear from the analysis that, farmers in the head reach of MID managed tank incurred lower transaction cost than tail end farmers. This calls for the rejuvenation of the defunct institution and ensure the equitable distribution of water between head and tail end. This helps in reduction of transaction cost incurred by tail reach farmers in MID managed tank area.

Total transaction cost incurred was high in MID managed tank or defunct water users association (₹ 1,06,085 per year) than farmers managed tank or active water users association ( $₹$ 61,480 per year). This is because of free riding problem that prevailed in the MID managed tank command. Bhattarai and Bhusal (2015) reported that, transaction cost was high in the area with free riding than the area where they control free riding. Senaratne and Karunanayake (2006) revealed that, lowest average transaction cost was reported in farmers managed village tanks ( $₹ 25,088$ per year) than the one managed by sub-group ( $₹ 35,717$ per year) and third party ( $₹ 54,535$ per year). The results are in line with the study conducted by Gururaj (2018) where it was noticed that, transaction cost was high in moderately performing water users cooperative society than better performing water users cooperative society.

Transaction cost per ha per year was ₹ 491 and ₹ 2,782 in farmers managed and MID managed tanks, respectively (Table 4). Hence, the hypothesis that transaction costs of governance are less in the tank managed by farmers than by MID was accepted. Increase in enforcement cost per member ( $₹ 2,591$ and ₹ 331 in MID managed tank and farmers managed tank, respectively) due to defunct water 
users association in MID managed tank was ₹ 2,260. Transaction cost per member was ₹ 769 and ₹ 2,652 in farmers managed tank and MID managed tank, respectively (Table 4). The results of the study thus emphasize the need for active water users association to reduce the transaction cost.

\section{ACKNOWLEDGEMENTS}

The author would like to thank all the farmers and the Minor Irrigation and Groundwater Development Board, Chikkamagaluru who spared their valuable time in providing the information and to DST, GoI for providing INSPIRE fellowship to undertake the study.

\section{CONCLUSION}

Transaction cost was more in the tank managed by the farmers through collective action than the tank managed by MID. Institutions are transaction cost reducing mechanism. Transaction cost in MID managed tank was more for the farmers in the tail end reach compared to head reach farmers. Free riding and illegal extraction of water enhanced the guarding time of the tail reach farmers resulting in higher transaction cost. Hence, such institutions which result in lowering the transaction cost must be adopted wherever transaction costs are high. Educating the farmers regarding the benefits of collective action is necessary to reduce the transaction cost. There is a need to rejuvenate the defunct institution to ensure collective action and achieve equity in distribution of water between head and tail end users in the tank managed by Minor Irrigation Department (Ayyanakere).

\section{REFERENCES}

Anonymous, 2000. The Karnataka irrigation and certain other laws (Amendment) act, Karnataka Act No.24. Government of Karnataka, Bengaluru.
Bhattarai, R.C. 2010. Assessment of transaction costs in farmer's managed irrigation system in Nepal. Econ. J. Dev. Issues, 11 \& 12 (1-2): 112-123.

Bhattarai, R.C. and Bhusal, T.P. 2015. Transaction costs and evolution of new institutions in farmers' managed irrigation system in Nepal. Econ. J. Dev. Issues, 19 \& 20 (1-2): 1-21.

Coase, R.H. 1960. The Problem of Social Cost. J. Law and Econ., 3(1): 1-44.

Durga, A.R., Chandran, K. and Suresh, K.D. 2015. Economic analysis of transaction costs of water users' associations in South India. Int. Res. J. Agric. Econ. and Statistics, 6(2): 392-402.

Gandhiraj, V. 2007. Decline of tank irrigation institutions in South India - A case-study of Tamil Nadu. Paper presented at the National Seminar on Water and Culture, Hampi.

Gururaj, B. 2018. Institutional economic analysis of canal water irrigation in Tungabhadra command area of Karnataka. Ph.D Thesis (Unpub.), Univ. Agric. Sci., Bengaluru.

Kolla, S. and Chandrakanth, M.G. 2013, Transaction cost analysis of benefits received from Governmental programmes by farmers in Krishna District of Andhra Pradesh. Mysore J. Agric, Sci., 47(2): 368-373.

Ostrom, E., Lam, W.F. and Lee, M. 1994. The performance of self-governing irrigation systems in Nepal. Human Systems Management, 13(3): 197-207.

Palanisami, K. 2006, Sustainable management of tank irrigation systems in India. J. Dev.in Sustainable Agric., 1: 34-40.

Senaratne, A. and Karunanayake, K. 2006, Transaction costs and institutional innovation: Sustainability of tank aquaculture in Sri Lanka (SANDEE Working Paper No 1807). South Asian Network for Development and Environmental Economics (SANDEE), Kathmandu.

Sripadmini, R. 2001, Relative economic performance of watershed development projects under different management protocols in Karnataka, M.Sc (Agri) Thesis, (Unpub.), Uni. of Agri. Sci., Bangalore. 